回回回回回

PHILOLOGIA CLASSICA
DE PHILOLOGIS

ET PHILOLOGIA
回回回回回

VOL. 14. FASC. 1. 2019

UDC 821.14

\title{
A Tale of Two Manuscripts*
}

\section{Michael M. Pozdnev}

St. Petersburg State University,

7-9, Universitetskaya nab., St. Petersburg, 199034, Russian Federation; m.pozdnev@spbu.ru

For citation: Michael M. Pozdnev. A Tale of Two Manuscripts. Philologia Classica 2019, 14(1), 131143. https://doi.org/10.21638/11701/spbu20.2019.110

The post-Renaissance copies of Aristotle's Poetics were mostly made for scholarly use. The copyists such as Anton Salvini, a Florentine polymath, librarian and professor of Greek, drew on MSS as well as on printed editions in an attempt to establish the text they could use for translation or academic teaching. Still uncertain remains the rationale of the latest known manuscipts - from the Vatopedi monastery on Mt. Athos (ca. mid 18th cent.) and from Bucharest (of the early 19th cent.). Several similarities these copies display suppose common provenance. The Greek diaspora in Bucharest blossomed around 1800 and Romania is linked to Vatopedi by a long tradition of orthodox learning. The MSS in question provide an overall impression of a schoolwork. The Athoan is of supreme quality while the Romanian often resembles an abstract. The first MS was probably written soon after the foundation of the Athonite Academy near Vatopedi. Aristotle's Poetics is hardly suitable for monastic learning, but Eugenius Bulgaris who was the headmaster of Athonias from 1753 to 1758 introduced ancient texts into its curriculum: from one of his letters we conjecture that Plato and Aristotle were studied there. It is thus reasonable to suppose that the cod. Vatopedius was made in the Athonias for learning purposes. By 1800 the Academy was in decline but they still taught disciplines and read texts introduced by Bulgaris. So, the Bucarestensis could have been written in the same place. Judging by the composition of the codex its maker was nurturing interest in ancient and modern Greek literature.

Keywords: Aristotle, Poetics, manuscripts, Athonias Academy, Bulgaris.

* This article was prepared within the framework of Russian Science Foundation research project № 18-18-00060. The author cordially thanks Svetlana S. Dubova who studied and collated the Bucharest MS of Aristotle's Poetics, Dr. Francesca Gallori of the Marucellian Library, and father Philip, a curator of the Old Library of Vatopedi, whose advice substantially influenced the present work. Special thanks must here be made to Prof. Dieter Harlfinger for his valuable consultations and Dr. Pantelis Golitsis, who greatly helped the participants of this project in working with MSS microfilm copies in the Aristotle's Archive of Freie Universität Berlin.

(C) St. Petersburg State University, 2019 
Among the known MSS of Aristotle's Poetics quite a few are written long after the invention of printing. The considerable amount of Cinquecento copies ${ }^{1}$ is not surprising, but there are three dating from late 17 th or early 18 th century, Marucellianus A 109, Parisinus suppl. gr. 0488 and Bibl. Britannica, Burney $64,{ }^{2}$ and two of even later date, Athous Vatopedius $778^{3}$ and Bucarestensis gr. 59 (Litzica 749), the latter made most probably after $1800 .{ }^{4}$ However popular the Poetics was with the post-Renaissance men of letters, scholars, teachers etc., its admirers must have had some ad hoc reasons for copying the text by hand despite the possibility to consult numerous and excellent printed editions. ${ }^{5}$ What could these reasons possibly be?

To be sure, nobody would expect to discover within the text transmitted by the recentissimi any traces of independent tradition. They have never been collated let alone thoroughly studied from historical (codicological, paleographical) viewpoint. Still, they can reflect the trends of users' interest which is not altogether unimportant, considering what text is referred to. The collation, now in progress, allows to assume that the 17th-19th century copies are largely based on printed books. The same is already true for the late Cinquecento MSS that reproduce a number of vulgate readings found in the 1508 editio princeps by Aldus Manutius (the famous Rhetores Graeci) as well as the emendations made by Pietro Vettori in his 1560 Florentine edition (Commentarii in primum librum Aristotelis de Arte Poetarum, the 2 nd revised ed. appeared in 1573). ${ }^{6}$ This is not astonishing, as the Aldine in which Aristotle's Poetics modestly follows the Progymnasmata of Aphtonius the "Sophist" was a great rarity ${ }^{7}$ and could take value of a faithful witness, while the innovative Vettori's edition served later critics as a standard to evaluate manuscript readings. In Parisinus 0488 Poetica is also preceded by Aphtonius' Progymnasmata and so this MS is likely to depend on the Aldine, though the copyist most certainly drew from the manu-

1 They reach ten in number: Matritensis 4805 (N 92), Berolinensis Phillippicus 1599 (196), Parisinus gr. 2551, Ambrosianus P 34 sup. (Martini-Bassi 617), Riccardianus 15, Riccardianus 16, Ferrarensis Cl. II. 348, Parisinus gr. 2117, Ravennas 381, and possibly Monacensis gr. 360 which we have not been able to study yet. For dates of MSS and further references see esp. Lobel 1933; Wartelle 1963; Harlfinger 1971 and https://pinakes.irht.cnrs.fr/recherche-generale/results/page.

2 The date and provenience of Marucellianus is discussed below; for the date of Burney MS see also Pattie, McKendrick 1999 and esp. Thompson 1889, 442.

3 Description: Eustratiades 1924, 152-153. Eustratiades dates the codex to the 18th century.

4 Cf. Litzica 1909, 499; Chiron 2001, 41.

5 Among them six voluminous 16th cent. commented eds. (Robortello, Maggi-Lombardi, Vettori, Castelvetro, Piccolomini, Riccoboni) and the highly elaborated Aristotelis De poetica liber by Daniel Heinsius edited in 1610 and again in 1611 (text., transl. and comm. supplemented by an exegetic treatise) on request of Elsevier.

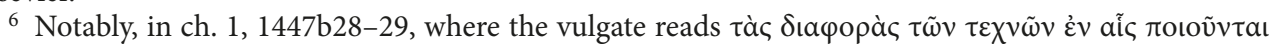

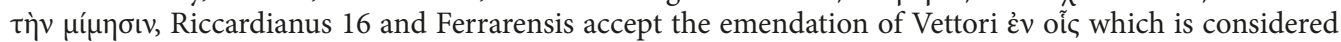
appropriate by Bywater, Kassel and all the editors of the last decades. A majority of late copyists seem to have used the Guglielmo and Alessandro de' Pazzi's bilingual edition printed in Venice in 1536: cf., for instance,

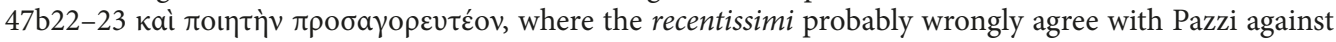

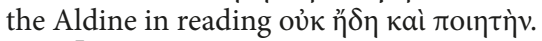

7 Esp. vol. 2 containing scholia. An anonymous reviewer of the monumental edition by Chr. Waltz cites as famous anecdote: "Wyttenbach erzählt, dass Hemsterhusius ungeachtet der eifrigsten Nachforschung kein Exemplar erlangte”: G. B. 1835, 114; cf. Sicherl 1992, 111. The price of $£ 21510$ for which the book ( 2 vols.) was recently sold at Christie's should be considered low, since it certainly is one of the last in private hands. 
script sources as well, sharing peculiar mistakes with some of the later ones. ${ }^{8}$ Angelo Maria Bandini (1726-1803), a Florentine librarian, collated in 1777 four Laurentian copies of the Poetics (Laur. gr. 31.14, 60.14, 60.16 and 60.21) using Vettori's text as gauge: This curious early document of textual studies is preserved at the Marucellian library, where Bandini was appointed as first director (MS B.III.55). In the same collection there is a codex which contains chapters 1-9 of the Poetics written some decades earlier by another Tuscan scholar, Anton Maria Salvini (1653-1729): Marucellianus A 109 is the only late MS whose authorship can be identified so far. As a classicist Salvini gained renown for his Tuscan translations of ancient authors (he translated the whole of Homer and Hesiod), so one might assume that in copying the Poetics he aimed to provide a reliable text for translation which he first planned, but then changed his mind for something different. Like Bandini, he consulted printed editions ${ }^{9}$ and had old manuscript copies before his eyes, since he first tried to reproduce archaic letter forms, notably that of "nu" similar to "mu", but lacking consistency finally abandoned the imitative manner and confined himself to habitual graphemes. The 17th-18th century MS of the Burney Collection with its limpid albeit not decorative calligraphy distantly resembling the accurate ductus of Salvini seems to have been produced for some scholarly purpose as well. Still, Charles Burney would hardly have acquired the codex, if it had no value other than that of a reader's copy. Collation shows, indeed, that alongside with printed books its author has drawn on the 15th-16th century MSS. ${ }^{10}$ In fact, Burney 64 and Marucellianus A 109 appear to descend from the same origins: a number of chapter headings is found only in these two copies, and they contain both Bindefehler and Trennfehler. ${ }^{11}$ Whatever the intention of the post-Renaissance manuscript makers was (one could easily imagine them teaching, translating or commenting on the Poetics), while writing down the text they aimed at improving on it, and since in their age textual criticism was at its birth stage, they felt free to interpolate into the (already deeply contaminated) text from any source available to them, be it a manuscript or a printed edition, any reading they considered best.

All this can be true for the contemporaries of Salvini or Mabillon and Montfaucon, and explains the nature of Marucellianus, Parisinus and Burney, as these are by no means an exception. ${ }^{12}$ But a century later the making of manuscript copies was already quite an unusual practice among scholars. No one would intend to do it, unless some collector would order such a copy, ${ }^{13}$ which is definitely not the case with Athous, and even less with

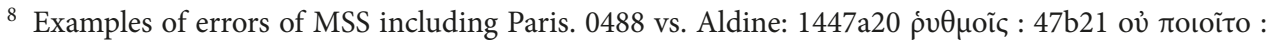

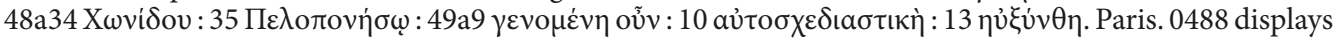

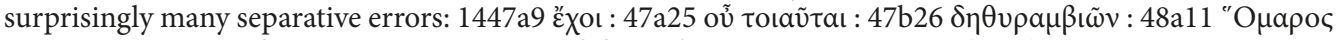

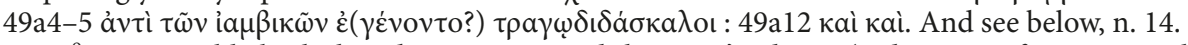

${ }_{9}$ Conceivably both the editio princeps and the Pazzi's edition (indicative is for instance the omission

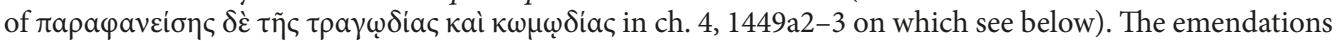
by Vettori are either ignored or not accepted.

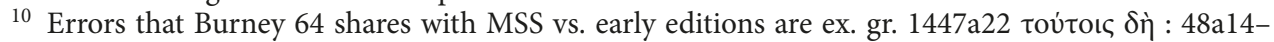
$15 \delta ı \theta v \rho a ́ \mu \beta о v \varsigma$ кaì toù vó ral of good quality, it has only a small number of omissions and mistakes of its own.

${ }_{11}$ 1449a2-3 Burney reproduces without omission (see n. 9). Marucellianus has $\eta \dot{\xi} \xi \dot{v} \theta \eta$ instead of

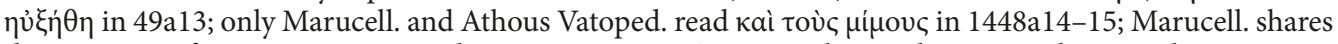
the omission of $\gamma \grave{\alpha} \rho$ in 48a30-31 and erroneous à $\gamma \rho \iota \omega \tau \dot{\alpha} \tau \omega v$ in $48 \mathrm{~b} 12$ with Burn. and some other MSS.

12 Some typical examples are to be found in: Lutz 1975.

${ }^{13}$ Cf. ibid. 265-267: the Aldine edition of Hero and Leander was meticulously copied about 1800 on request of some wealthy collector, probably Sir John Thorold. 
Bucarestensis written both in a quick cursive hand, the latter in a rather slipshod manner. The last quires of Ath. contain an arithmetic course book dated 1818. The date of the Poetics MS in Ath. will be discussed hereinafter, but it cannot possibly be earlier than 1750s. In Buc. Aristotle is preceded by versified texts in demotic Greek; the author might well have been inspired by the rise of Greek national spirit on the eve of Independence War. The chapter headings in Buc. coincide exactly with those of the 1788 bilingual edition by Lauritz Sahl (a professor of Greek at Copenhagen, his 2nd revised ed. of 1802 is more frequently referred to), thus providing the terminus post quem. So, the question remains: why these two copies came to be made?

In fact, what is most striking about Ath. and Buc. is their similarity. It becomes clear at first glance that they originate from the same school of writing: though ductus is individual to each of them, specific common features such as copulating letters with accents in $\delta \varepsilon \tilde{\imath}$ and $\varepsilon \dot{\imath} \iota$, a loop-like tau, a lambda with its angle sharpened and lowered deep below the line, are fairly obvious (cf. illustrations 1 and 2). Collation has revealed so far only one peculiar common mistake, resulting from an interpretative gloss, ${ }^{14}$ but given the interpolated character of these MSS and their possible sources this affords another argument for their affinity. Naturally enough, they both display a number of mistaken readings and lacunas of the vulgate. ${ }^{15}$ Yet, the Romanian copy abounds in yawning gaps of its own that increase in length around the middle of the treatise, the last MS pages containing little

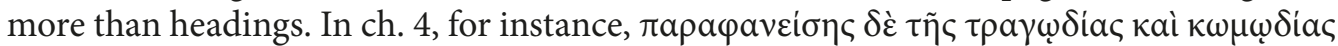
(1449a2) is left out in the Aldine and several late copies including Marucellianus and Ath. (in some 15th cent. MSS it is added in the margin), because the eye of a scribe got stuck to

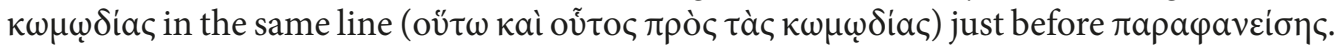
In Buc. the line is also missing, but its maker deliberately excluded the subsequent lines too, picking the text up again pretty recklessly with $\kappa \omega \mu \omega \delta$ ía at $49 \mathrm{a} 10(\kappa \omega \mu \omega \delta i \alpha, \kappa \alpha i ̀ ~ \dot{\eta}$

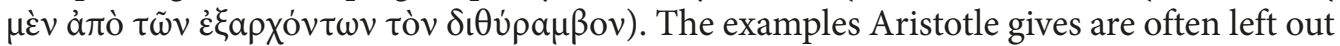
in Buc., including the key ones like that of Homer and Empedocles in ch. 1, $1447 \mathrm{~b} 18$ or Oedipus and Thyestes in ch. 13, 1453a11. Having passed over a major part of ch. 13, the scribe realized that something important should yet be noted and wrote down in brackets:

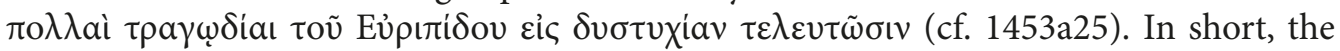
Bucharest MS with its 10 sparsely filled pages leaves an impression of an abstract made by a very negligent scholar or a student who witnessed the demise of his school. Quite the opposite is the case with Athous, whose maker did an accurate work in reproducing on 26 pages, with nice colophon and coda, all the virtues and flaws of the pattern text (or texts).

Concerning the lasting tradition that joins Romania with Athos as well as the density and influence of the Greek diaspora in Bucharest that reached its peak by the end of the 18 th century ${ }^{16}$ it is not hard to guess where the traces lead. Aristotle's Poetics is, of course, hardly suitable to monastic learning. It never entered the medieval academic curriculum

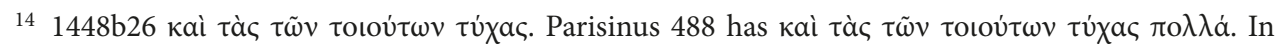
Ch. $1,1447 \mathrm{~b} 26$ Ath. and Buc. read $\dot{\eta} \tau \tilde{\omega} v \mu \dot{i} \mu \omega v$ sharing this very peculiar mistake probably stemming from a common source with Marucellianus and Parisinus.

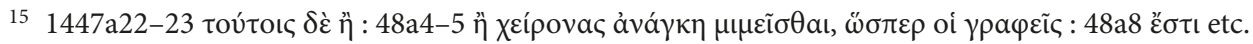

16 See Katsiardi-Hering 2012, Cândea 1996 and esp. Coman 2012 with links to further reading. Many of those "scholars, preachers, mystics and saints" of the Enlightenment age, who "moved continuously in and out of Athos" (Kitromilides 1996, 258), were teaching in Romania. 
nor the repertoire of monastery scriptoria. ${ }^{17}$ The fact is, however, that from the mid-18th till the early 19th century a very peculiar educational institution known as Athonite Academy functioned on Mount Athos in the immediate vicinity of the Vatopedi Monastery. The history of its rise, progress and decay has been reconstructed in main outlines, ${ }^{18}$ but a detailed monographic study still remains a desideratum despite the great importance commonly attributed to this institution as one of the leading schools of Greek nation which paved the way for its liberation from the Ottoman rule. Whatever the reasons for this reticence, he who today comes close to the impressive ruins of the Athonias, might stop and think as he reads the words scratched by some learned traveller on a rusty gate tablet: hoc loco stultitia superavit scientiam.

As to the relevance of this charge, a word will be added later, insofar as it relates to our present subject. Lacking more precise information on the Athonias' school program designed probably by Meletius, the learned prohegumenos of Vatopedi, ${ }^{19}$ we can but conjecture that it was framed in the usual disciplines of a mediaeval monastic school, i. e. "logic, philosophy and theology", 20 taught in classical Greek. The language course was given a great deal of importance within the curriculum, in which it was included from the very beginning. This we know from the official agreement concluded with the Vatopedi brothers by the school's first headmaster, a somewhat conservative orthodox scholar Neophytus Kausokalybitis (1713-ca.1784), ${ }^{21}$ on December 1st 1749 . Along with the duties

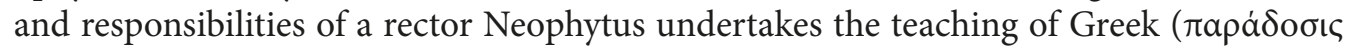

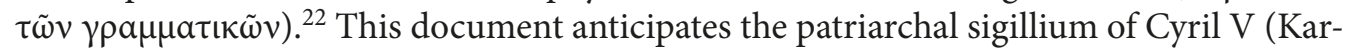
akallos) that settled formal matters concerning the functioning of the school. Cyril was the driving force behind this entire educational experiment, of which we gain some idea from Athous Vat. 778 encompassing, as noted above, a voluminous course of arithmetic in perfectly readable Byzantine Greek. Indeed, such strict enforcement of teaching Greek was a risky undertaking, especially as the textbook the monks used was, most probably, the Grammar of Gennadius (Georgius Kourtesius) Scholarius, the first Constantinople patriarch under the Turks. ${ }^{23}$ This manual is still being applied for practical teaching in the monastery of Vatopedi, where Gennadius retired in 1456, and it is with his famous Пepi $\tau \tilde{\omega} v \theta \alpha v a \sigma i \mu \omega \nu$ kà $\sigma v \gamma \gamma \nu \omega \sigma \tau \tilde{\omega} v \alpha \alpha \mu \alpha \tau \eta \mu \alpha \dot{\tau} \omega \nu$ that our Athoan codex opens. After three years Neophytus had to abandon his duties, while the total number of Athonias students

17 It is left to conjecture how cod. Meteorensis, Metamorph. 91 of the late 15 th cent. written by Michael Suliardus (Harlfinger, Reitsch 1970, 39) came into the possession of the Metamorphosis Monastery.

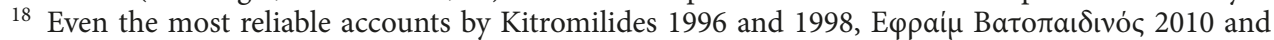

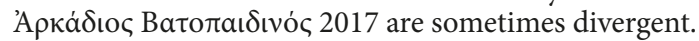

19 Bishop Meletius took the initiative of establishing the school. He owned a number of manuscripts, among them most valuable ones now preserved in the Vatopedi library: Kitromilides 1998, 325-326, n. 2.

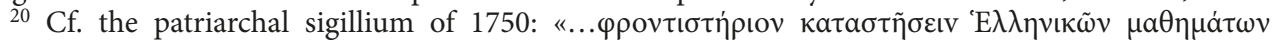

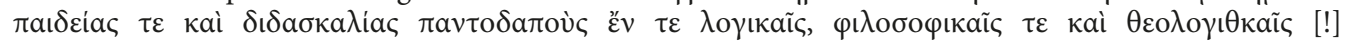

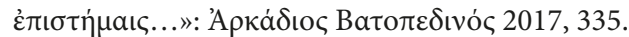

${ }^{21} \mathrm{He}$ was one of the initiators of the reactionary 'Kollyvades Movement' much discussed in the orthodox scholarship: Patapios, Chrysostomus 2006, 27-45; https://www.johnsanidopoulos.com/2017/04/ neophytos-kavsokalyvites-1689-1784.html. Since 1770 he preached in Romania. More on his teaching: Camariano-Cioran 1974, 413-431.

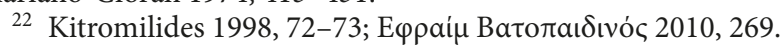

${ }^{23}$ On his life, works and influence see Blachet 2008; Demetracopoulos 2018, 129-178, esp. 155. Several MSS by his hand are preserved in the Vatopedi library. The Grammatica of Constantine Lascaris and the Syntax of Theodor Gaza were also used by the Athonias teachers such as Panagiotis Palamas who also read

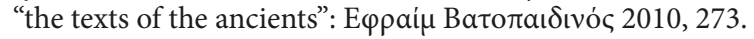


hardly exceeded 20. ${ }^{24}$ Agapius Agiotaphites (born 1710) chosen as his successor in the spring of 1752 had no time to carry out any reform, because in August of the same year he was murdered by Janissaries. ${ }^{25}$ However, only a few weeks later Cyril was reinstalled on the patriarchal see and with his habitual vigor applied himself to reanimation of his favourite creation. New funding opportunities were launched, and new school building with students' rooms, a library, headmaster's quarters and a chapel arose. ${ }^{26}$ In what concerns the educational strategy, the patriarchal sigillium of 7th July 1753 is very clear: the programme should include "Greek lessons, and education and teaching of every kind of the sciences of logic, philosophy and theology". ${ }^{27}$ Apparently, Cyril's ambitions grew, but still Greek comes first in plan, so he needed a rector able to integrate ancient language and up-to-date scientific content in classroom teaching, and arouse an interest for both in orthodox students. He addressed Eugenius Bulgaris, the only academic teacher of that time who could meet these criteria.

The life of Bulgaris (1716, Corfu -1806, St. Petersburg) is, of course, well known, though his early career is documented more sporadically as compared with the decades he spent in Constantinople, Germany and Russia. ${ }^{28}$ During the last century of Turcocracy a number of orthodox gymnasia functioned in the Greek speaking world supported by patriotically-minded merchant families. Bulgaris started his career as a scholarch in 1742 in one of such institutions founded in Ioannina by brothers Maroutsis: he met them in Padua where he studied at the University while supporting himself by teaching in a local Greek school. At Maroutsaia he taught mathematics and philosophy and fascinated many with his practice of fusing ancient literature with contemporary natural science. How such a fusion could function on the background of strict orthodoxy, is anyone's guess, but it found both passionate followers and influential foes. The latter managed even to summon Bulgaris away from Ioannina; ${ }^{29}$ for a short period he headed the "Stoa" school in Kozani adding lustre to its name, and then was called back to Maroutsaia, from where he moved to Athonias in 1753 following the patriarch's call. In his edict of 1753, Cyril commends the educational approach of "kyr Eugenius" by calling him "the wisest of teachers", and a person "capable of training pupils not only in grammar and the art of logic but in philosophy and mathematical sciences and in theology and those things which belong to moral philosophy". ${ }^{30}$ What promised to be pedagogically beneficial about the curriculum here sketched was obviously the belief that the ancient concepts should be challenged in what regards sensible objects (since within the course of philosophy Bulgaris also taught physics ${ }^{31}$ ), whereas in the field

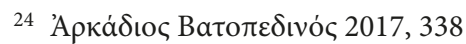

${ }^{25}$ We know about it from the letter by Bulgaris, a friend and possibly former teacher of Agapius:

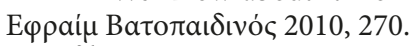

${ }_{26}$ See Kitromilides 1998, 74, 78-79 and 326; idem 1996, 264. Illustrations 3 and 4 below (cited after

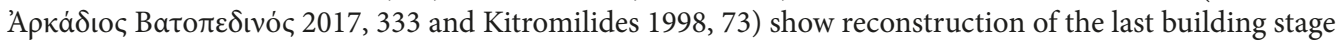
(1785) and modern ruins with the view on Vatopedi monastery.

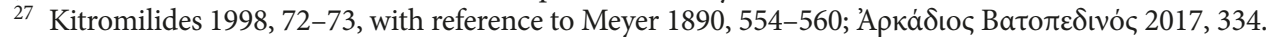

28 See Batalden 1982; Knapp 1984; Ko入oßov́ 2002; Gavrilov 2010. All authors provide further references for vast literature.

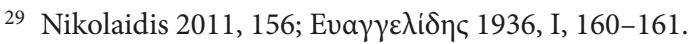

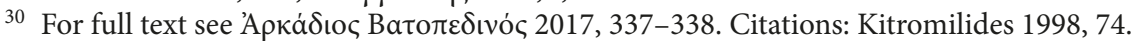

31 On his courses in the Athonias: Kitromilides 1992, 30-32 with further references; on his engagement with Newtonian physics: Pantiotis 2007. Bulgaris also taught Latin and was fluent in reading, writing and speaking classical Greek (though his written language inevitably absorbs demotic elements). However, he never taught Greek grammar. 
of humanities they virtually never become dated and thus should be studied alongside with or even previously to the modern ones. This principle is well illustrated by the content of the Athoan codex we are dealing with which includes ancient texts on the philosophy of language, classical prosody and literary theory that is Plato's Cratylus, Hephaestion's Encheiridion and Aristotle's Poetics.

These difficult pagan texts would have very little chance of enriching the orthodox academy's program, had it not been supported by the charismatic personality of Bulgaris. (In illustration 5 he is portrayed in an idealizing manner as an ordinary monk with a somewhat romantic but strong-willed look: this is how the Vatopedi brotherhood still conceives him.) Yet, he needed like-minded assistants, especially the skilled Greek teachers, like his former Marutsaia student and friend Cyprian of Cyprus, a deacon in Constantinople and later Alexandrian patriarch, to whom Bulgaris addressed an invitation letter dated $1756 .{ }^{32}$ In convincing Cyprian to come and help he displays much eloquence. He describes at some length the natural beauty of the place with its "verdant flora" and many charming birds "their voices ringing round here and there, and vying with these youths, nourished by the Muses, as they study in all freedom". What follows is an equally poetic description of what they study:

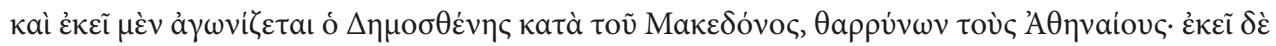

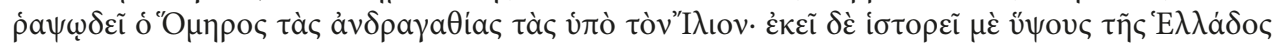

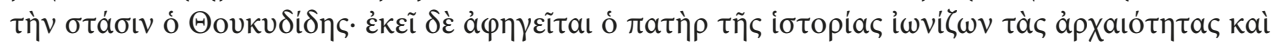

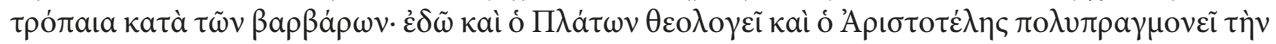

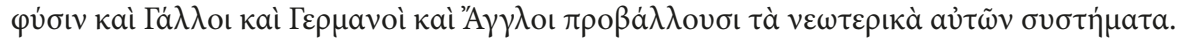

"And there Demosthenes strives against the Macedonian, encouraging the Athenians; there Homer recites poems about the deeds of courage and virtue at Ilium, there Thucydides describes with sublimity the discords of Hellas, there the father of history tells in Ionian style of antiquities and trophies won from the barbarians. And here Plato theologizes and Aristotle explores all kinds of questions concerning nature, and the French and Germans and English advance their innovative systems."

Aristotle and Plato are juxtaposed, just as in our codex, preceded by historians, a poet and an orator and followed by new European thinkers. The ancients represent humanities, while Descartes, Leibniz, Locke, Newton and the like are implicitly made responsible for exact and natural sciences. Hence the "exploring of nature" does not mean "physics" but the Aristotelian manner of philosophizing, and does not exclude the poetics, no more than its opposite, the "theologizing" of Plato which cannot possibly denote "theology" to an orthodox thinker, excludes the philosophy of language as it is exposed in the Cratylus.

As follows from the quoted lines, reading ancient authors was practised in the Academy. For this purpose, texts were copied from MSS (many of them were in private ownership) but mostly from printed books (and the Vatopedi library still preserves several old editions of the Poetics). Consequently, it can be supposed with good reason that the Poetics of the Vatopedi MS was copied in the Athonite Academy during the directorship of Bulgaris. But even if it is not so, it must have been him who introduced Aristotle's aesthetic treatise into monastic reading circle at the blossoming time of Athonias, when the school numbered several hundred students coming from all the Mediterranean, of whom many

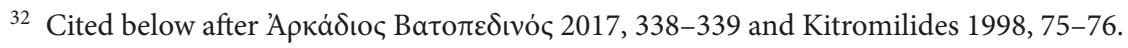


have left their mark on the history of Greek enlightenment, ${ }^{33}$ and when on the gate, where nowadays the above-cited pessimistic statement is scrawled, the proud motto was placed

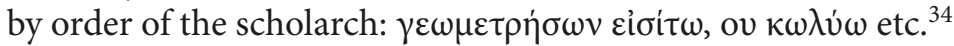

This time did not last long. Eugenius' appeals have gone unheeded: in spite of all the keen rhetoric of his letter culminating in demand to "draw the plough for the benefit of the nation", Cyprian did not take over the teaching of Greek, Neophytus retired to hermit's

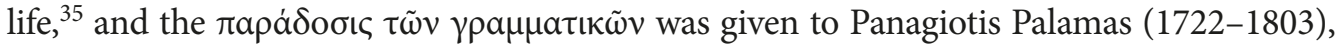
a person of traditional learning, with whom the opposition to Bulgaris novelties reared its head. ${ }^{36}$ In 1756 the conflict seems to have reached a flash point, since the rector strived not only to lure a like-minded teacher with promises of life in locus amoenus, but also to gain support from the patriarch, to whom he addresses in quite a different style: Kúpıє $\sigma \tilde{\omega} \sigma o v$,

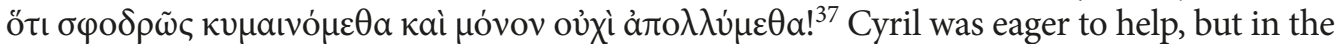
beginning of the next year he was deposed, came to Athos and tried to personally influence the situation. This finally severed his ties with Bulgaris who after two years of struggle had to leave the place. In 1759 he became head of the Patriarchal Academy in Constantinople where his Athonite students followed him in 1761, after Nicolaus Zerzoulis of Metsovo (1710-1773), who was meant to teach along the same lines as Bulgaris, ${ }^{38}$ also had to resign.

For Athonias it was the beginning of the end, and though the school lasted further and conspicuous effort was undertaken to revive it in the last decades of the 18th century, it dwelt on the memories of Bulgaris' days, trying to remain true to the spirit of his teaching. While applying for financial aid to Constantine Ipsilantis the Vatopedi fathers stressed that in the Academy, which still had four classes, they teach "grammar and the Logic of kyr Eugenius" (one of Bulgars most eminent works, printed in Leipzig in 1766, of which many students' copies are kept in the Vatopedi library). The letter bears no date, but since Ipsilantis is addressed as "the Great Dragoman of the Porta" it must have been written between 1796 and $1799 .{ }^{39}$ Around 1800 an attempt was made to breath a new life into the Academy by appeals for assistance from the Greek communities of the diaspora. In 1803 Adamatios Korais wrote triumphantly about the civilizing mission of the "University on Athos" ${ }^{40}$ All this gives additional clues to the date of our Rumanian MS. As noted above, it borrows the chapter headings from the text edited by L. Sahl firstly in 1788 and then in 1802. The Poetics in Bucarestensis is preceded by the Rhetoric to Alexander. In 1800 the 5th volume of Aristotle's complete works, in which these two texts are arranged in the same order, was edited

33 On the famous alumni of Athonias see Kitromilides 1996, 263-267. Among them are highly diverse personalities, broad=minded persons and supporters of the Enlightenment ideas as Iosipos Moisiodax and Gabriel Callonas, and the traditionalists like a church historian Sergius Macraeus or Athansius of Paros (who later became scholarch). St. Cosmas the Aetolian was one of Bulgaris' pupils.

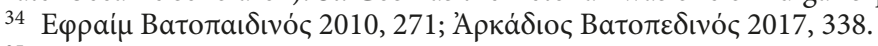

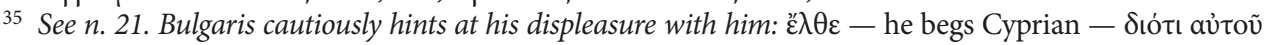

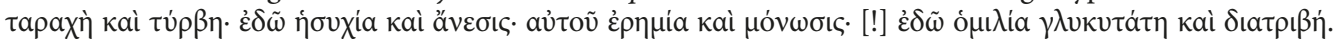
However, Bulgaris never quarreled with this scholar, whom he knew from Ioannina, and "despite his subsequent trouble with the grammarians at the school, considered Neophytos one of his friends": Kitromilides 1996, 261.

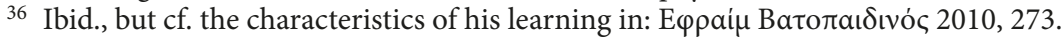

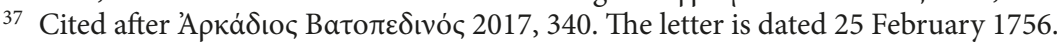

38 Kitromilides 1998, 77: "A philosopher, able mathematician, professor at the Patriarchal Academy in Constantinople, and the man who introduced Newtonian physics into Greek education.” He was supported by patriarch Seraphim II who invited Bulgaris to Constantinople. Nicolaus left Athonias after Seraphim lost his throne.

39 Kitromilides 1998, 79.

40 Id. 1996, 262. 
by Johann Gottlieb Buhle. The edition proved to be influential, especially as regards the Rhetoric to Alexander, ${ }^{41}$ and since the order is not so obvious, we might assume that Buhle's text was among the sources of an Athonite student of "grammar" in early 1800s. The maker of Buc. copied an ancient treatise chosen for school reading by "kyr Eugenius".

The Academy near Vatopedi monastery was officially closed in 1809 by patriarch Gregory V who is celebrated for his martyrdom in 1821. But this is not where the story

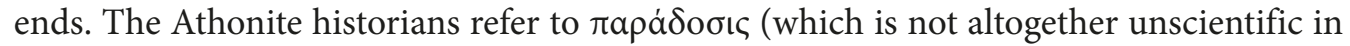
dealing with Athos monasteries) according to which in 1811 there still existed a school on that place. ${ }^{42}$ As the reader already knows, the arithmetic textbook in Cod. Vatopedius

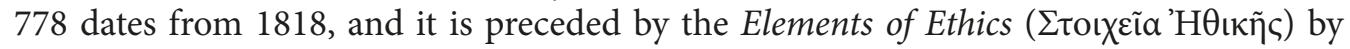
Benjamin of Lesbos (ca. 1760-1824) written about 1812. It is very likely that the life in Athonias came to a full stop only with the beginning of the Independence War. There hardly was any regular teaching or learning on Athos at that time. But there still were learned people and students interested in ancient and modern poetics. The songs and poems in demotic Greek that open the Bucharest codex and the annotated verses in Turkish that close it ${ }^{43}$ might point to the sentiments that prevailed in the Academy in its last turbulent years, when Rhigas Feraios took refuge in Vatopedi, ${ }^{44}$ and when Greek scholars and teachers could have hoped, as the Italian teachers a century ago actually did, that studying the Aristotelian Poetics could revive the great poetry of their past.

The romantic dreams nurtured perhaps by the early 19th century Greek intellectuals like Korais were bound to remain unrealized. The "Athonite University" was finally ruined and that not so much because of funding shortage or lack of appropriate teaching stuff. The rising national spirit of the Greeks would have easily overcome these and suchlike obstacles. The main risk factor lied in the nature of monastic way of thinking and learning, virtually incompatible with reading into philosophical texts created in tradition other than Christian. We can promptly exemplify this with our Bucharest MS of the Poetics which, as said above, is very lacunar, most of the omissions comprising the examples Aristotle draws on to illuminate some of his main points. In proving the cognitive nature of aesthetic pleasure he remarks: "though the objects themselves may be painful to see, we delight to

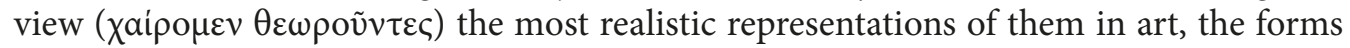
for example of the lowest animals and dead bodies" (ch. 4, 1448b10-12, transl. I. Bywater).

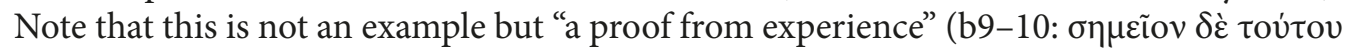

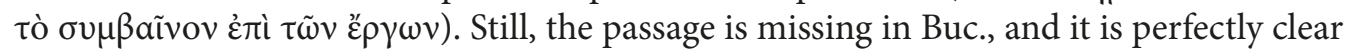
why the orthodox readers should not believe that they "view with delight" the images ( (1765-1821) wrote prophetically that if a high school were to be founded on Athos "it would be destroyed in a short while". ${ }^{45}$ Praestat venerari quaedam, quam scrutari, goes the much admired saying. ${ }^{46}$ So, it is not the "stupidity" that prevented the progress of

${ }^{41}$ It was used among other German philosophers by F. Schegel: Krause 2001, 71 with n. 143.

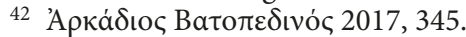

43 The headings and page numbers are given in: Litzica 1909, 499.

${ }^{44}$ It is told that Velestinlis even studied there for some time under scholarch Athanasius: E $\varphi$ pai $\mu$

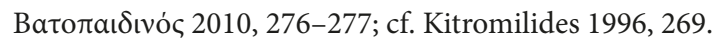

45 Ibid. 262.

46 The words belong to Erasmus and are cited by Pfeiffer 1976, 75 alongside with et scientiae pars est quidem nescire. Pfeiffer comments on this as follows: "What this expresses is not a trivial skepticism, but the natural shyness of religious men, their fear of transgressing the limits of human reason". 
"knowledge" in a monastic world, and one is left to wonder, how the tradition of studying ancient texts, to which our two late copies of Aristotle's Poetics owe their emergence, still continues to exist on Mt. Athos, in the heart of mystic Orthodoxy, over an unbridgeable schism between piety and science, between the old and the new.

\section{References}

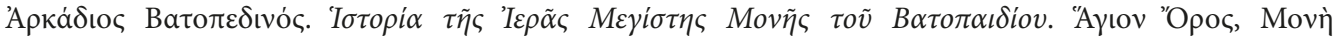
Ватолаıбíov, 2017.

Batalden S. K. Catherine II's Greek Prelate: Eugenios Voulgaris in Russia, 1771-1806. New York, Columbia University Press, 1982.

Blanchet M-H. Georges-Gennadios Scholarios (vers 1400-vers 1472). Un intellectuel orthodoxe face à la disparition de l'empire byzantin. Paris, Éditions de l'Institut Français d'Études Byzantines, 2008.

Camariano-Cioran A. Les académies princières de Bucharest et de Jassy et leurs professeurs. Thessalonike, Institute for Balkan Studies, 1974.

Cândea V. L' Athos et les Roumains, in: A. Bryer, M.Cunninngham (eds). Mount Athos and Byzantine Monasticism. Papers from the Twenty-Eighth Spring Symposium of Byzantine Studies. Birmingham, March, 1994. Aldershot, Variorum, 1996, 249-256.

Chiron P. La tradition manuscrite de la Rhétorique à Alexandre : prolégomènes à une nouvelle édition critique. RHT 2001, 30, 17-69.

Coman C. Moldavians, Wallachians, and Romanians on Mount Athos, in: W. Graham Speake, Kallistos Ware (eds). Mount Athos. Microcosm of the Christian East. Bern - Oxford, Peter Lang, 2012, 113-135.

Demetracopoulos J. A. Scholarios' On Almsgiving, or How to Convert a Scholastic "Quaestio" into a Sermon, in: D. Searby (ed.) Never the Twain Shall Meet? Latins and Greeks Learning from Each Other in Byzantium. Berlin — Boston, De Gruyter, 2018, 129-178.

Eustratiades S., Monk Arcadios of Vatopedi. Catalogue of the Greek Manuscripts in the Library of the Monastery of Vatopedi on Mt. Athos. Cambridge, MA., Harvard University Press, 1924.

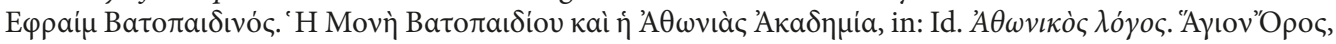

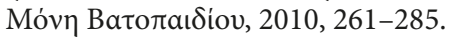

G. B(ernhardy?). [rec.] Rhetores Graeci. Ed. Chr. Walz. Vols. I-VII, 1832-1833. Allgemeine Literaturzeitung Mai, 1835, 96, 113-143.

Gavrilov A.K. On Philologists and Philology: Articles and Speeches. Ed. by O. Budaragina, A. Verlinsky, D. Keyer. St. Petersburg, SPb. University Publishing House, 2010, 65-70 (in Russian).

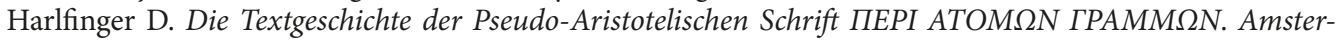
dam, Adolf M. Hakkert, 1971.

Harlfinger D., Reitsch D. Die Aristotelica des Parisinus gr. 1741. Zur Überlieferung von Politik, Rhetorik, Physiognomonik, De signis, De ventorum situ. Philologus 1970, 114, 28-50.

Katsiardi-Hering O. Greek Merchant Colonies in Central and South-Eastern Europe in the the Eighteenth and Early Nineteenth centuries, in: V.N.Zakharov, G.Harlaftis, O. Katsiardi-Hering (eds). Merchant Colonies in the Early Modern Period. London, Vermont, Pickering \& Chatto, 2012, 127-140.

Kitromilides P.M. Athos and the Enlightenment, in: A. Bryer, M.Cunninngham (eds). Mount Athos and Byzantine Monasticism. Papers from the Twenty-Eighth Spring Symposium of Byzantine Studies. Birmingham, March, 1994. Aldershot, Variorum, 1996, 257-272.

Kitromilides P. M. The Enlightenment as Social Criticism: Iosipos Moisiodax and Greek Culture in the Eighteenth Century. Princeton, Univ. Press, 1992.

Kitromilides P.M. Vatopaidi and the Greek Cultural Tradition: The Contribution of the Athonite Academy, in: Vatopedi Fathers (eds). The Holy and Great Monastery of Vatopedi. Tradition - History - Art. Vol I. Mt. Athos, The Monastery, 1998, 72-80; 325-326.

Knapp M. Evjenios Vulgaris im Einfluss der Aufklärung: Der Begriff der Toleranz bei Vulgaris und Voltaire. Amsterdam, Hakkert, 1984.

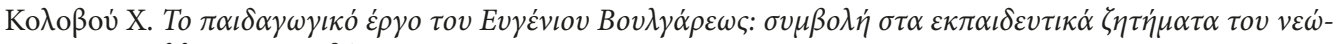
$\tau \varepsilon \rho o v \varepsilon \lambda \lambda \eta v \iota \sigma \mu o v ́$. А $\theta \dot{v} v \alpha$, ЕКПА, 2002.

Krause P.D. Unbestimmte Rhetorik: Friedrich Schlegel und die Redekunst um 1800. Tübingen, Max Niemeyer, 2001. 
Litzica C. Bibliotheca academiei române. Catalogul Manuscriptelor Grecești. Bucharest, Instit. de Arte Grafice «Carol Göbl», 1909.

Lutz C. E. Manuscripts Copied from Printed Books. The Yale University Library Gazette 49 (3), January 1975, 261-267.

Lobel E. The Greek Manuscripts of Aristotle's Poetics. Oxford, OUP, 1933.

Maunde Thompson E. Classical Manuscripts in the British Museum, CR 1889, 3, 149-155; 440-445.

Meyer Ph. Beitrage zur Kenntnis der neueren Geschichte und des gegenwärtigen Zustandes der Athosklöster. Zeitschrift fü̈ Kirchengeschichte 1890, 11, 395-435; 539-576.

Nikolaidis E. Science and Eastern Orthodoxy: From the Greek Fathers to the Age of Globalization. Transl. S. Emanuel. Baltimore, John Hopkins Univ. Press, 2011.

Sicherl M. Die Aldina der Rhetores Graeci (1508-1509) und ihre handschriftlichen Vorlagen. Illinois Classical Studies 1992, 17(1), 109-134.

Pantiotis M. Periphery reassessed: Eugenios Voulgaris converses with Isaac Newton. The British Journal for the History of Science 2007, 40, 471-490.

Hieromonk Patapios, Archbishop Chrysostomus. Manna from Athos. The Issue of Frequent Communion on the Holy Mountain in the Late Eighteenth and Early Nineteenth Centuries. Oxford - Bern, Peter Lang, 2006.

Pattie T., McKendrick S. The British Library Summary Catalogue of Greek Manuscripts, London, George Bell \& Sons, 1999.

Pfeiffer R. History of Classical Scholarship: 1300 to 1850. Oxford, Clarendon Press, 1976.

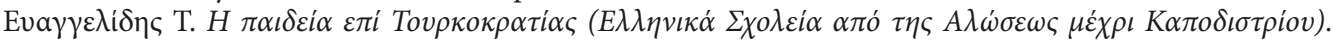

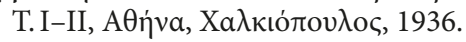

Wartelle A. Inventaire des manuscrits grecs d'Aristote et ses commentateurs : contribution à l'histoire du texte d'Aristote. Paris, Belles Lettres, 1963.

\section{Appendix: Illustrations}

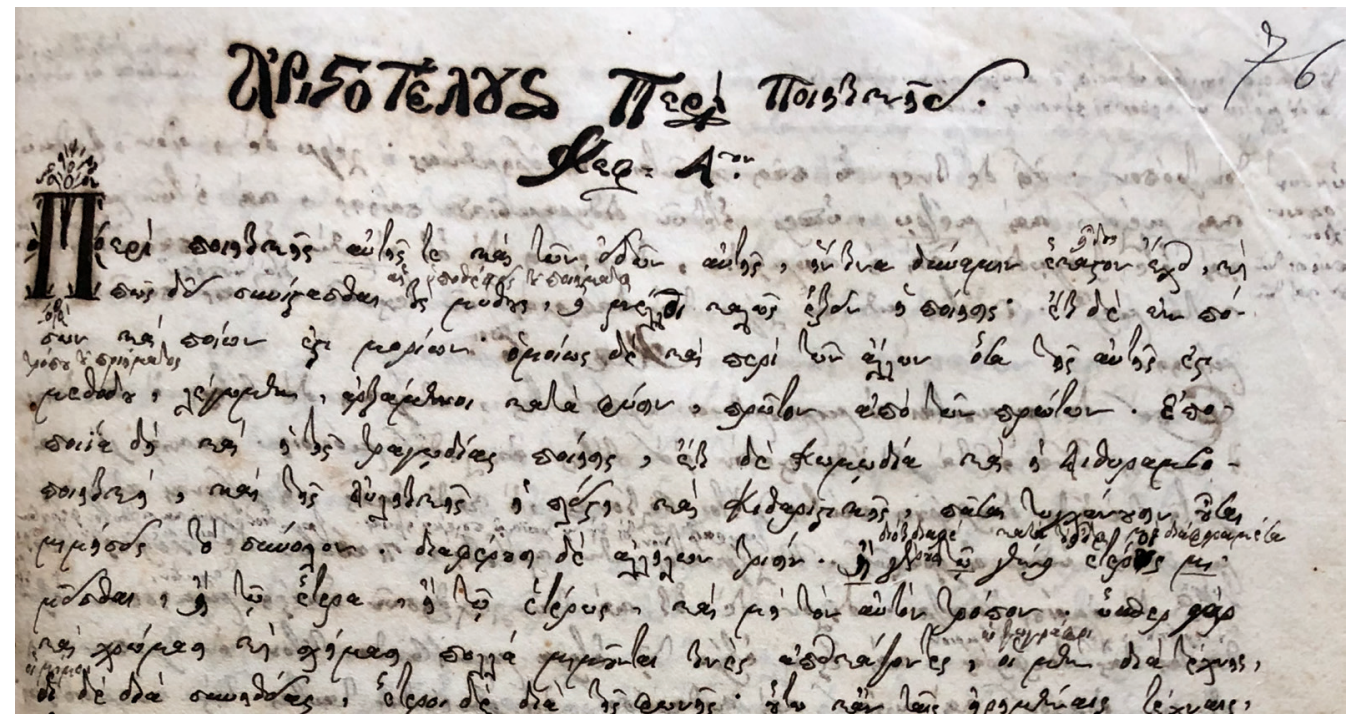

Ill. 1. Cod. Athous Vatopedius Athous Vatopedius 778, Old Library of Vatopedi (fragment) 


$$
\begin{aligned}
& \text { ricisonizous areinach ars } \\
& \text { K4?: a? }
\end{aligned}
$$

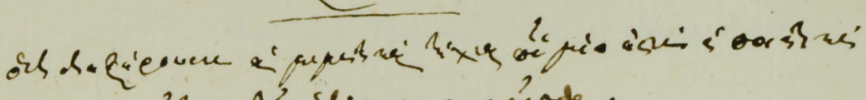

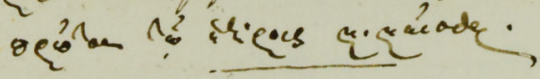

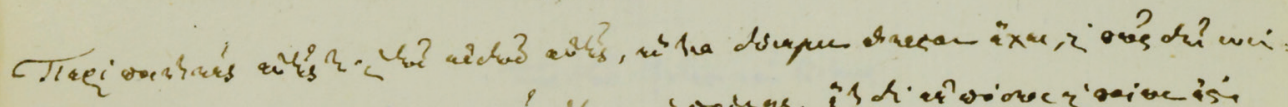

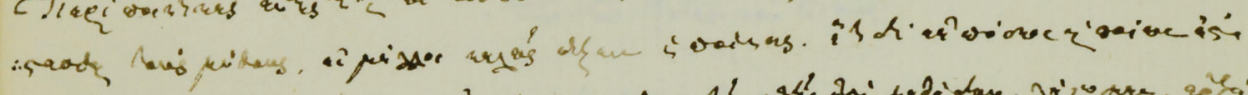

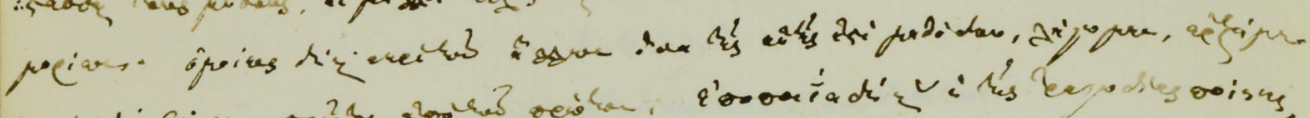

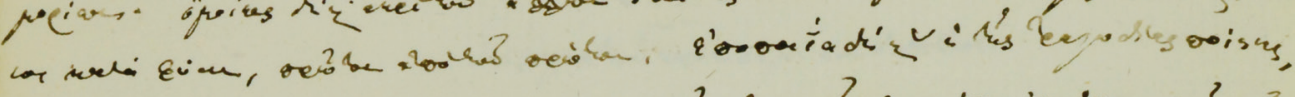

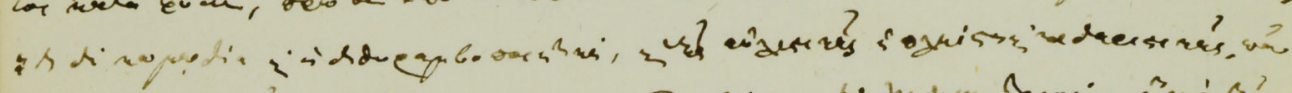

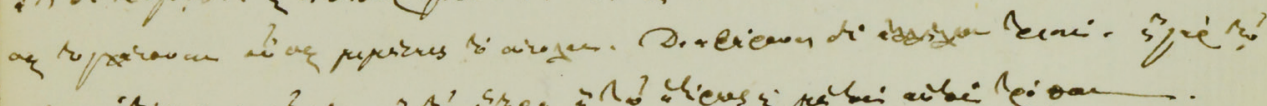

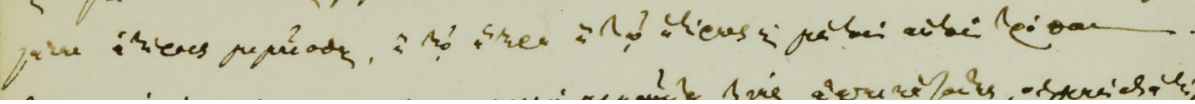

Ill. 2. Cod. Bucarestensis gr. 59 = Litzica 749, Biblioteca Academiei Române (fragment)

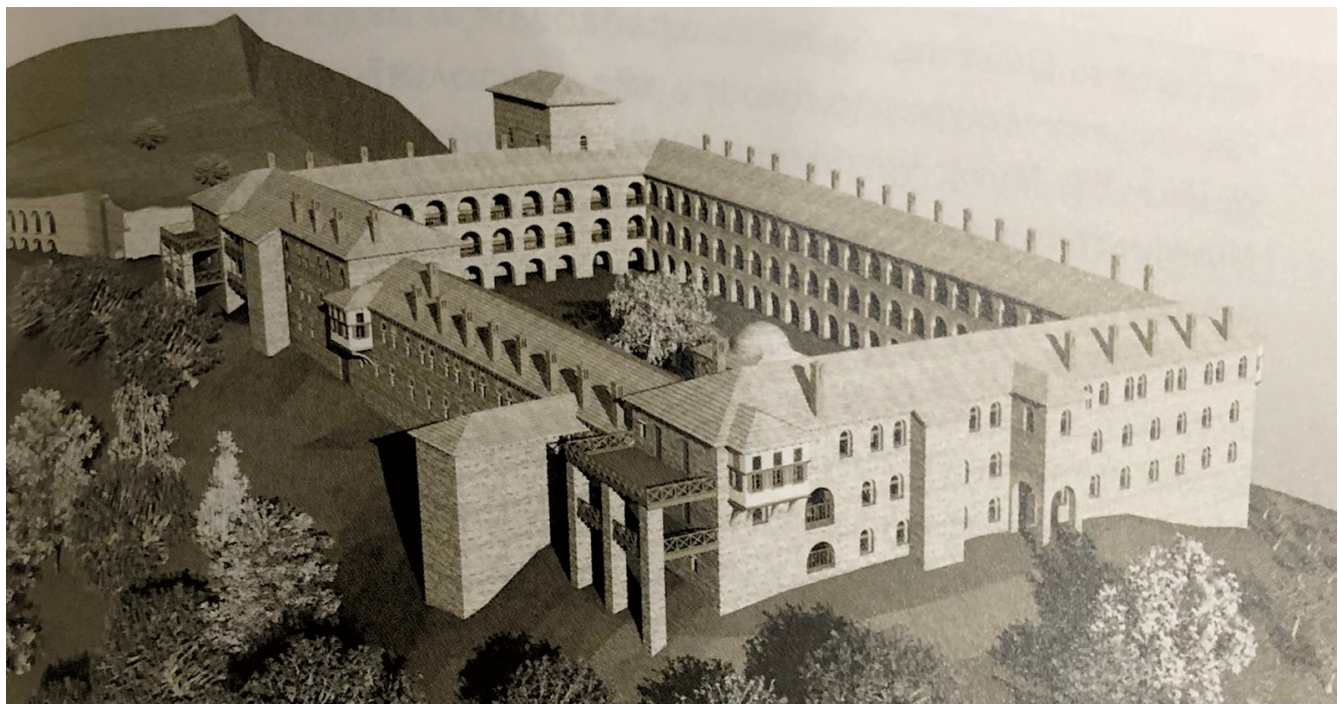

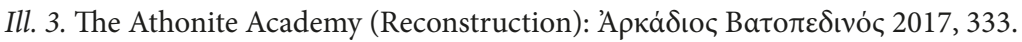




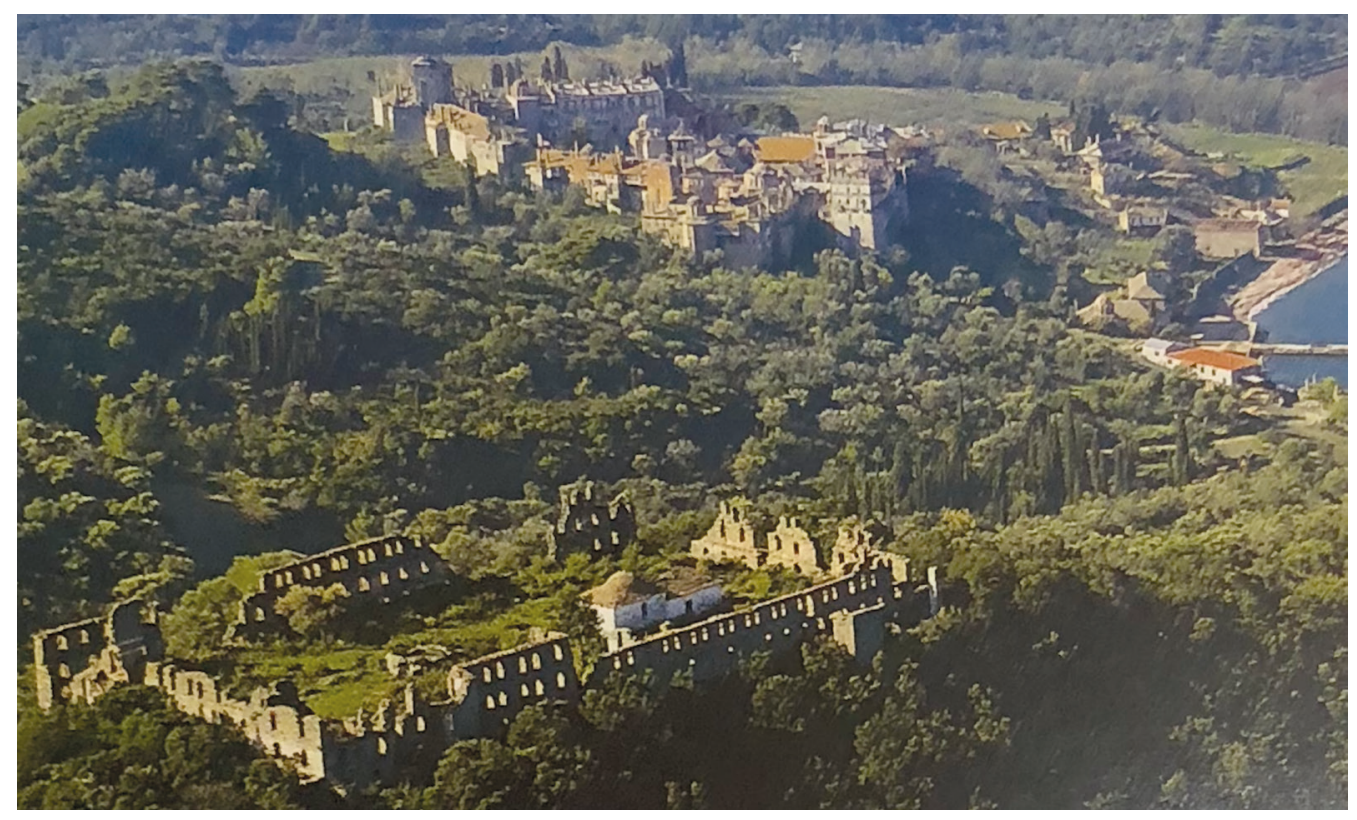

Ill. 4. Ruins of the Athonias with view on Vatopedi monastery: Kitromilides 1998, 73.

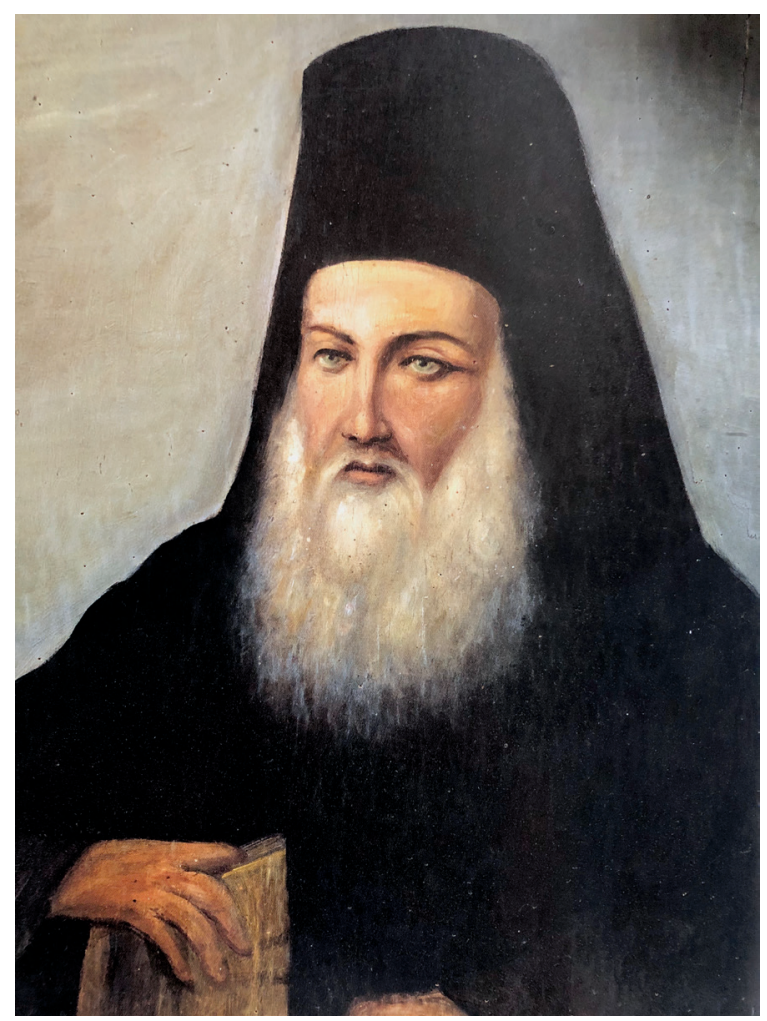

Ill. 5. Eugenius Bulgaris, after: Orthodox Calender for 2018 ed. by the Holy Monatery of Vatoped, Caryes, Athos 2018. 